\title{
A serologic investigation for Equine Viral Arteritis and Equine Infectious Anemia Virus Infections in Horses in Afyonkarahisar, Ankara and Eskişehir Provinces, Turkey
}

\author{
Duygu BAKİ ACAR ${ }^{1}$, Sibel GÜR ${ }^{2 *}$, Metin GÜRÇAY ${ }^{3}$, Erhan ÖZENÇ$^{1}$ \\ ${ }^{1}$ Afyon Kocatepe University, Faculty of Veterinary Medicine, Department of Obstetrics and Gynaecology, 03200, Afyonkarabisar / TURKEY \\ ${ }^{2}$ Afyon Kocatepe University, Faculty of Veterinary Medicine, Department of Virology, 03200, Afyonkarahisar / TURKEY \\ ${ }^{3}$ Bingöl University, Faculty of Veterinary Medicine, Department of V irology, 12000, Bingöl / TURKEY \\ Corresponding author e-mail: sibelgur@aku.edu.tr
}

\section{ABSTRACT}

Equine arteritis virus (EAV) was classified in the Arteriviridae family, and cause to abortus and disorders in alimentary and respiratory system. Equine Infectious Anemia virus (EIAV) is a Lentivirus into Retroviridae family. Both infections have worldwide dissemination. The aim of this study is to investigate these infections as serologically in horses from Ankara, Eskişehir and Afyonkarahisar provinces. A total of 204 (173 female, 31 male) samples were controlled using indirect ELISA. EAV specific antibodies were detected in $22(10.8 \%)$ animals (20 female and 2 male). The ratios of EAV seropositive horses were $4.2 \%$ and $12.4 \%$ in the Afyonkarahisar and Eskissehir provinces, respectively, while all the sera samples were found to be negative from Ankara province. All of the samples were negative for EIAV as expected. As a result, both virus infections were investigated for the first time in the horse population in Afyonkarahisar and Eskişehir provinces.

Key Words: ELISA, Equine Infectious Anemia Virus, Equine Viral Arteritis, Horse

\section{Türkiye'de Afyonkarahisar, Ankara ve Eskişehir İllerinde Equine Viral Arteritis ve Equine Infectious Anemia Virus Enfeksiyonlarının Serolojik Olarak Araştırılması}

\section{ÖZ}

Equine Arteritis Virus (EAV), Arteriviridae ailesi içinde sınıflandırılmakta ve abortus ile sindirim ve solunum sistemi bozukluklarına neden olmaktadır. Equine Enfeksiyöz Anemi Virusu (EIAV) ise bir Lentivirus'dur ve Retroviridae ailesi içinde yer almaktadır. Her iki enfeksiyon da dünya çapında yayılım göstermektedir. Sunulan çalışmanın amacı, bu enfeksiyonların Ankara, Eskişehir ve Afyonkarahisar illerinde bulunan atlarda serolojik olarak araştırılmasıdır. Toplam 204 (173 dişi, 31 erkek) adet örnek indirekt ELISA kullanılarak test edildi. Alınan örneklerin 22 adetinde (\%10.8; 20 dişi, 2 erkek) EAV spesifik antikor tespit edildi. Afyonkarahisar ve Eskişehir'den alınan at serumlarında EAV seropozitif örnek oranı sırasıyla \%4.2 ve \%12.3 olarak belirlenirken, Ankara'dan alınan örneklerin tamamının negatif olduğu tespit edildi. Tüm serum örneklerinin EIAV test sonuçları beklenildiği üzere negatif olarak saptandı. Sonuç olarak, bu çalışma ile Afyonkarahisar ve Eskişehir'de bulunan at populasyonunda her iki virus enfeksiyonu ilk kez araştırılmıştır.

Anahtar Kelimeler: ELISA, Equine Infectious Anemia Virus, Equine Viral Arteritis, At

To cite this article: Baki Acar D, Gür S, Gürçay M, Özenç E. A serologic investigation for Equine Viral Arteritis and Equine Infectious Anemia Virus Infections in Horses in Afyonkarahisar, Ankara and Eskişehir Provinces, Turkey. Kocatepe Vet J. 2016; 9(3):159-164. 


\section{INTRODUCTION}

Equine arteritis virus (EAV) was classified in the Arteriviridae family, in order Nidovirales (Snijder and Meulenberg, 1998; Cavanagh et al. 1999). The agent is an enveloped, single stranded, positive sense RNA virus. The infection was well documented in horses since first identification in USA in 1953 (Bryans et al. 1957). Worldwide disseminated infection was not reported from Japan and Iceland (Kondo et al. 1998; Holyoak et al. 2008). Donkeys, mules and alpacas are also susceptible to the virus (Paweska and Barnard 1993; Paweska et al. 1996; Paweska et al. 1997; Weber et al. 2006). The pathogenetic features of the infection are well-documented in horses (Timoney et al. 1986, 1987; Del Piero et al. 1997). The infection described as "abortion storm". The agent can be transmitted via venereal and horizontal way. Experimental infections shows that, alimentary and respiratory disorders are common (Timoney and McCollum 1993, Del Piero et al. 1997). Low level of virus was detected in ovarian tissue and follicular fluid of mares (Holyoak et al. 2001). There were controversial findings about histopathological basis of abortion. Viral antigen was demonstrated within smooth muscle cells of the myometrium (Wada et al. 1995) and areolar trophoblast (Del Piero et al. 1997). This hypothesis was supported by some studies with no lesions on the fetal tissues. However, MacLachlan et al. (1996) were reported that, virus titer values of aborted fetuses were higher than its dams. This evidence indicated that there was substantial virus replication in the fetus. Outcomes of these studies reveal that combination of both maternal and fetal pathologies resulted with abortion.

Equine Infectious Anemia virus (EIAV) is widespread infection of horses and all equidae. The agent was classified into the family Retroviridae, genus Lentivirus. As typical Lentivirus, the target cells were monocytes and macrophages (Montagnier 1985). The horizontal transmission of the EIA virus from one horse to another occurs by bloodsucking insects (Issel and Foil, 1984). The most important transmission ways of the virus are blood transfer from infected to healthy horse and placental transmission from infected mares to their offspring by vertically. In addition, the virus could be transmitted to the foals via infected milk consuming from their mother or nursing (Stein and Mott 1946, 1947). In vitro embryo production procedure has been using more common recently, but a potential risk via infected embryo transfer was shown (Gregg and Polejaeva 2009). Tissue distribution of the virus is broad; including liver, spleen, kidney, lung, lymph node and adrenal gland (McGuire et al. 1971). Clinical courses of the EIAV infection can be seen as acute, chronic and subclinical forms. After nearly two months later, the first findings can be observed as a high fever, a drop in platelet and a high virus titer in the body. Later on, chronic stage starts with recurrent disease episodes. These animals became carrier following chronic period for rest of their life (Montelaro et al. 1993).

According to scientific reports conducted in many parts of Turkey, EVA rates were varied between 5\% (Yilmaz et al. 1996) and 23.4\% (Bulut et al. 2012). Turkey seems free from EIAV infection in accordance with numerous studies into last two decades (Burgu et al. 1989; Turan et al. 2002, Yapkıł̧ et al. 2007; Marenzoni et al. 2013).

The purpose of this study is to investigate the EAV and EIAV infections serologically in Ankara, Eskişehir and Afyonkarahisar provinces in horses and to reveal first data on presence and proportion in Afyonkarahisar and Eskişehir provinces.

\section{MATERIALS AND METHODS}

\section{Sampled Animals}

Blood serum samples were collected from different locations from Afyonkarahisar $\left(38^{\circ} 45^{\prime} \mathrm{N}-30^{\circ} 33^{\prime} \mathrm{E}\right)$, Ankara $\left(39^{\circ} 56^{\prime} \mathrm{N}-32^{\circ} 52^{\prime} \mathrm{E}\right)$ and Eskişehir $\left(39^{\circ} 46^{\prime} \mathrm{N}-\right.$ $\left.30^{\circ} 22^{\prime} \mathrm{E}\right)$ provinces, Turkey. All of the sampled horses were randomly selected among adults (older than 1 year old). Due to general breeding aim and habits, out of 204 animals only 31 was stallion.

The samples were collected from private small and medium scale enterprises. Breeding aim was different; horse racing, stud animals, companion horses and pack horses in rural areas of these provinces. A part of horses were standard bred and Arabian race horses, however, nearly $60 \%$ of the animals have been breeding in an organized purebred stud farm.

All animals were clinically normal during sampling. Detailed health records could not obtained from standard bred horses due to the lack of regular health recording system. Any preventive health applies like vaccination has not been applying due to unprofessional breeding habits. In the other organized farms, routine vaccinations have been performing for some viral and bacterial infections, as Equine Herpes Virus 1/4 (EHV1/4), Equine Rhinopneumonitis, Antrax, etc. All of the animals were not vaccinated for EVA. EIA virus had eradicated from Turkey previously, by the way there is no vaccination protocol in the throughout country. Blood samples were drawn from Vena Jugularis into vacutainer tubes containing silicone, and transported to the laboratory at $+4^{\circ} \mathrm{C}$. The blood samples were centrifuged at $3000 \mathrm{rpm}$ for $10 \mathrm{~min}$. and serum fractions were separated into stock tubes, and stored at $-20^{\circ} \mathrm{C}$ until the test.

Enzyme Linked Immunosorbent Assay (ELISA) Sera samples were controlled for EVA virus specific $\mathrm{Ab}$ using an indirect ELISA test (ID Vet, France), and for EIA virus specific $\mathrm{Ab}$ detection, a 
competitive EIA (IDEXX, USA) kit was utilised. The tests were carried out according to producer's instructions. The plates were read in $450 \mathrm{~nm}$, and each OD values were calculated.

\section{RESULTS}

A total of 204 horses were tested for EAV and EIA virus. The antibodies against EAV were detected in $22(10.8 \%)$ animals (20 female and 2 male). The ratios of seropositive horses were $4.2 \%$ and $12.4 \%$, in the Afyonkarahisar and Eskişehir provinces, respectively, while all the sera samples were found to be negative from Ankara province. EIAV specific antibodies were not detected in any of the studied horses.

Table 1: Serological test results of EVA and EIA infections

Tablo 1: EVA ve EIA enfeksiyonların serolojik test sonuçları

\begin{tabular}{llccc}
\hline No & Localisation & $\begin{array}{c}\text { Animal } \\
\text { Number }\end{array}$ & $\begin{array}{c}\text { EVA } \\
(\mathrm{Ab} / \%)\end{array}$ & $\begin{array}{c}\text { EIA } \\
(\mathrm{Ab} / \%)\end{array}$ \\
\hline 1 & Ankara & 11 & - & - \\
2 & Afyon & 24 & $1(4.2)$ & - \\
3 & Eskişehir & 169 & $21(12.4)$ & - \\
\hline & Total & 204 & $22(10.8)$ & - \\
\hline
\end{tabular}

\section{DISCUSSION}

EVA infection has important impact on gynaecologic parameters. The infection was described with abortion and newborn deaths (Bryans et al. 1957, Newton et al. 1999), and has nearly world-wide dissemination (Timoney and McCollum 1988). There was an increase in outbreaks in last decades especially in Europe, such as England (Newton et al. 1999) and France outbreaks (Pronost et al., 2010). In Germany, seroprevalence was risen up to 20\% from 1.8\%, between 1987 and 1994 (Eichorn et al. 1995). Reported serologic data; 55.1\% in Poland (Rola et al. 2011), 15\% in Mongolia (Pagamjav et al., 2011), 73\% in Australia (Huntington et al. 1990). According to a recent study in Iran, EVA antigen and antibody presence were reported as $4.46 \%$ and $4.04 \%$ in 470 horses, respectively (Nejat et al. 2015).

There is no data on initial entrance of the EAV infection in Turkey. All scientific reports on the issue were carried out in last two decades. According to chronological order; 5\% in 1996 (Yllmaz et al. 1996), $9.5 \%$ and $8 \%$ values were reported in Kars and Ardahan provinces (Kırmızıül et al. 2007), 7.5\% in the Marmara region (Hasan 2008), 14.4\% in donkeys in Kars (Y1ldirim et al. 2008), 23.4\% in Central Anatolia (Bulut et al. 2012), 8.4\% in Şanliurfa (Ün et al. 2014) and $11.3 \%$ in Van (Gür et al. 2015). In this study, out of three studied province, seropositivity were determined in two. All of the samples from
Ankara was found to be negative, while 4.2\% (1/24) and $12.4 \%(21 / 169)$ proportions were determined in Afyonkarahisar and Eskişehir provinces, respectively. In total, out of 204 adult horses, 22 of them (10.8\%) were spent natural EVA infection. Previously, Bulut et al. (2012) were studied in Konya (19.2\%, 40/208), Kayseri (34\%, 30/88) and Ankara (22.6\%, 19/84). The higher rate of their study in Ankara could be explained by differences in sampled population. In addition, the number of sampled animals was low in our study; obtained data from Ankara was not enough to make a healthy evaluation.

The virus could be taken via direct contact with respiratory fluids, fomites, aerosol way and semen from acute infected animals and/or carrier stallions (Guthrie et al. 2003). After primary replication, viremia occurs and the virus is spread to lung and bronchial lymph nodes within 2 days post infection (pi), The agent can be isolated from buffy coat and other secrets on days 2-28 pi (Timoney and McCollum 1993). After acute infection, mares and geldings eliminate the virus within maximum 60 days. Seldomly, carrier state can be seen in respiratory system in prepubertal colts until 6 months old age. However, nearly $30-60 \%$ of the infected stallions could be stay carrier for a long time or lifetime. They shed the virus in the semen, but not in blood, respiratory secretions and urine (Timoney et al. 1986; Neu et al. 1987). This situation restricts the international horse movements and semen importation without laboratory controls in most of the countries of the world (Ahlswede et al. 1998; Balasuriya et al. 1998). The role of imported stallions or frozen semen in the outbreaks was outlined by many researchers (Metcalf 2001). In the present study, all of the mares were breeding by stallions naturally; artificial insemination was not in question. Breeding practices were totally traditional in the small private farms. Stallions can be used from the other stud farms in natural breeding season, also. In the organized horse farm, there were very few numbers of stallions but they have been keeping in separate units from the mares. According to transmission dynamics, incidence can be increase rapidly within farms. Horse racing conditions and contact with other horses in course of usage as a pack animal during daily works creates risk for exposure. Therefore, all of the transmission ways stated above could be valid in the sampling performed farms in this study. Because of horse breeding practices in Turkey, mares have been preferred for their mild temperament for the pack animal; this predilection was not valid in the purebred race horse farms.

EIAV infection was described initially in 1843 (Lignee 1843), later on, the clinical features was well defined in 1904 (Vallee and Carre, 1904). Today, the infection has been declared from America, parts of Europe, the Middle and Far East, Russia and South 
Africa (APHIS 2006, DEFRA 2006). In Turkey, the first declaration of the EIA was in a horse according to pathological findings in Ankara (Akçay 1953). The first outbreak was reported in 1952 in Sultansuyu state stud horse farm (Noyan 1958). In 1955, the infection was also detected in horses from different locations histopahologically (Hakioğlu 1955). After that, the infection was disappeared as a result of implemented proper precautions strictly, as it's supposed to be. Years later the infection was studied as serologically from various part of Turkey. Total of 294 sera from pure bred horse breeding state farms were found to be negative (Burgu et al. 1989). Following studies conducted on horse, mule and donkeys; 404 sera from Marmara Region (Turan et al. 2002), 406 serum from Central Anatolia (Yapkıç et al. 2007), 476 samples from Noth-East Anatolia (Kırmızıgül et al. 2009), 8.947 samples from Ardahan province (Albayrak and Ozan, 2010) and 346 samples from provinces at Marmara and Aegean Regions (Marenzoni et al. 2013) were controlled for EIA and all of them were verified as negative. In the present study, all of the samples from different farms in three provinces were determined as negative for the EIAV infection as expected.

EVA outbreaks could be seen time to time despite strict control measurement like vaccination, controlled semen usage, to prevent the importation of uncontrolled horses and testing all breeding stallions in developed countries. In Turkey, organized pure bred stud horse farms have been taking all necessary precautions. Even though total eradication has not been succeeded, economic and fertility disorders were reduced as much as possible. EIAV infection has not seen since mid 1950's, although considering newly introduced arboviral infections and increase in incidence of vector borne infections in Turkey, there might be risk for following years via live animal transportation and widen in vector habitat. Countrywide routine health monitoring survey system has not been held as it should be. Traditional breeding habits in rural areas in horses and donkeys creates obstacle in front of the control and total eradication of these and similar infections in the country.

\section{REFERENCES}

Ahlswede L, Leyk W, Zurmuhlen K. Studies on equine viral arteritis: serological investigations, virus detection in semen and aborted fetuses, and vaccination. Prakt Tierarzt. 1998; 24:18-25.

Akçay S. Yurdumuz atlarında anemi enfeksiyozun zuhuru ve anatomo-histopatolojik teşhisinin değeri. Türk Vet Hek Dern Derg. 1953; 76-77:479-505.

Albayrak H, Ozan E. Serosurveillance for equine viral infectious anemia in Ardahan province of Turkey. Trop Anim Health Prod. 2010; 42(8):1593-1595.

APHIS. Equine infectious anemia: uniform methods and rules effective. The United States
Department of Agriculture Publications, 2006, USA.

Balasuriya UB, Evermann JF, Hedges JF, McKeirnan AJ, Mitten JQ, Beyer JC, McCollum WH, Timoney PJ, MacLachlan NJ. Serologic and molecular characterization of an abortigenic strain of equine arteritis virus isolated from infective frozen semen and an aborted equine fetus. J Am Vet Med Assoc. 1998; 213:1586-9, 1570.

Bryans JT, Doll ER, Knappenberger RE. An outbreak of abortion caused by the equine arteritis virus. Cornell Vet. 1957; 47(1):69-75.

Bulut O, Yavru S, Yapici O, Kale M, Avc1 O. The serological investigation of Equine Viral Arteritis infection in Central Anatolia of Turkey. J Anim Vet Adv. 2012; 11(7):924-926.

Burgu İ, Akça Y, Toker A, Alkan F. Atlarda enfeksiyöz aneminin serolojik olarak araştırılması. A Ü Vet Fak Derg. 1989; 36(1):123-128.

Cavanagh D. Nidovirales: a new order comprising Coronaviridae and Arteriviridae. Arch Virol. 1999; 142(3):629-633.

DEFRA. Equine infectious anemia: potential risk factors for the introduction of the virus the Greate Britain from EU member states and countries neighbouring the EU. International Disease Monitoring Units Qualitative Risk Assessment. 2006, 1:1-16.

Del Piero F, Wilkins PA, Lopez JW, Glaser AL, Dubovi EJ, Schlafer DH, Lein DH. Equine arteritis virus in newborn foals: clinical, pathological, serological, microbiological and immunohistochemical observations. Equine Vet J. 1997; 29(3):178-185.

Eichhorn W, Heilmann M, Kaaden OR. Equine viral arteritis with abortions: serological and virological evidence in Germany. J Vet Med 1995; 42:574-576.

Gregg K, Polejaeva I. Risk of equine infectious anemia virus disease transmission through in vitro embryo production using somatic cell nuclear transfer. Theriogenology, 2009; 72(3):289-299.

Guthrie AJ, Howell PG, Hedges JF, Bosman AM, Balasuriya UB, McCollum WH, Timoney PJ, MacLachlan NJ. Lateral transmission of equine arteritis virus among Lipizzaner stallions in South Africa. Equine Vet J. 2003; 35(6):596-600.

Gür S, Çabalar M, Kaya A, Gürçay M. Van ilinde equine viral arteritis enfeksiyonunun serolojik olarak araştırılması. Kocatepe Vet J. 2015; 8:36-40.

Hakioğlu F. Yurdumuz atlarında anemia infectiose hastalığının teşhisi için karaciğerde histopaolojik araştırmalar. A Ü Vet Fak Yay. 1955; No:61. A Ü Basımevi, Ankara. 
Hasan S. Investigations on the frequency and diagnosis of Equine Arteritis Virus (EAV) infection in horses by virus isolation, molecular and serological techniques in the Marmara region. $\mathrm{PhD}$ thesis. Istanbul University Health Science Institute, Turkey, 2008.

Holyoak GR, Knight-Sherod J, Timoney PJ, McCollum WH, Spatz M. The presence of equine viral arteritis in reproductive tissues and follicular fluid from experimentally infected mares. In: Proceedings of the Society for Theriogenology Conference, p. 6.

Holyoak GR, Balasuriya UBR, Broaddus CC, Timoney PJ. Equine viral arteritis: Current status and prevention. Theriogenology 2008; 70:403-414.

Huntington PJ, Forman AJ, Ellis PM. The occurrence of equine arteritis virus in Australia. Aust Vet J. 1990; 67(12):432-435.

Issel CJ, Foil LD. Studies on equine infectious anemia virus transmission by insects. J Am Vet Med Assoc. 1984; 184(3):293-297.

Kırmızıgül AH, Yıldırım Y, Gökçe G. Kars veArdahanyöresindekiatlarda Equine Viral Arteritis enfeksiyonunun seroprevalansinin belirlenmesi. Kars Univ Vet Fak Derg. 2007; 13:171-175.

Kırmızıgül AH, Yıldırım Y, Gökçe E, Ataseven VS. Serologic evaluation of the equine infectious anemia in Kars and ArdahanTurkey. Kafkas Univ Vet Fak Derg. 2009; 15:77-80.

Kondo T, Fukunaga Y, Sekiguchi K, Sugiura T, Imagawa H. Enzyme-Linked Immuno sorbent Assay for serological survey of Equine Arteritis Virus in racehorses. J Vet Med Sci. 1998; 60(9):1043-1045.

Lignee M. Memoire et observations sur une maladie de sang, connue sous le nom d'anhemie hydrohemie cachexie aqueuse du cheval. Rec Med Vet. 1843; 20:30.

MacLachlan NL, Balasuriya UB, Rossitto PV, Hullinger PJ, Patton JF, Wilson WD. Fatal experimental equine arteritis virus infection of a pregnant mare: immune histochemical staining of viral antigens. J Vet Diagn Invest. 1996; 8:367-374.

Marenzoni ML, Cuteri V, De Parri1 F, Danzetta ML, Yılmaz Z, Yaramış ÇP, Kennerman E, Or ME, Marchi S, Casciari C, De Mia GM, Valente C, Costarelli S. A pilot study on the epidemiological status of equine infectious anaemia, equine viralarteritis, glanders, and dourine in Turkey. Turk J Vet Anim. Sci. 2013; 37:76-80.

McGuire TC, Crawford TB, Henson JB. Immuno fluorescent localisation of equine infectious anemia virus in tissue. Am J Pathol. 1971; 62:283-294.

Metcalf ES. The role of international transport of equine semen on disease transmission. Anim Reprod Sci. 2001; 68:229-237.

Montagnier L. Lymphadenopathie-associated virus: from molecular biology to pathogenicity. Ann Intern Med. 1985; 103:689-693.

Montelaro RC, Ball JM, Rushlow KE. Equine Retroviruses. In: Levy JA, eds. The Retroviridea. Plenium press; 1993. p: 257-360.

Nejat S, Momtaz H, Yadegari M, Nejat S, Safarpour Dehkordi F, Khamesipour F. Seasonal, Geographical Age and Breed Distribution of Equine Viral Arteritis in Iran. Kafkas Univ Vet Fak Derg. 2015; 21:11-116.

Neu SM, Timoney PJ, McCollum WH. Persistent infection of the reproductive tract in stallions experimentally infected with equine arteritis virus. In: Proceedings of the 5th International Conference Equine Infectious Diseases, 1987, p.149-154.

Newton JR, Wood JL, Castillo-Olivares FJ, Mumford JA. Serological surveillance of equine viral arteritis in the United Kingdom since the outbreak in 1993. Vet Rec. 1999; 145:511-516.

Noyan A. Anemia infectiosa equorumlu safkan arap atlarında hematolojik araştırma. A Ü Vet Fak Derg. 1958; 5:209-241.

Pagamjav O, Kobayashi K, Murakami H, Tabata Y, Miura Y, Boldbaatar B, Sentsui $\mathbf{H}$. Serological survey of equine viral diseases. Microbiol Immunol. 2011; 55:289-292.

Paweska JT, Barnard BJH. Serological evidence of equine arteritis virus in donkeys in South Africa. Onderstepoort J Vet Res. 1993; 60:155-158.

Paweska JT, Aitchison $H$, Chirnside ED, Barnard BJ. Transmission of the South African asinine strain of equine arteritis virus (EAV) among horses and between donkeys and horses. Onderstepoort J Vet Res. 1996; 63:189-196.

Paweska JT, Binns MM, Woods PS, Chirnside ED. A survey for antibodies to equine virus in donkeys, mules and zebra using virus neutralisation (VN) and enzyme linked immunosorbent assay (ELISA). Equine Vet J. 1997; 29:40-43.

Pronost S, Pitel PH, Miszczak F, Legrand L, Marcillaud-Pitel C, Hamon M, Tapprest J, Balasuriya UB, Freymuth F, Fortier G. Description of the first recorded mojor occurrence of equine viral arteritis in France. Equine Vet J. 2010; 42:713-720.

Rola J, Larska M, Rola JG, Bélak S, Autorino GL. Epizotiology and phylogeny of equine 
arteritis virus in hucul horses. Vet. Microbiol. 2011; 148:402-407.

Snijder EJ, Meulenberg JJ. The molecular biology of arteriviruses. J Gen Virol. 1998; 79:961979.

Stein CD, Mott LO. Equine infectious anemia in brood mares and their offspring. Vet Med. 1946; 41:274-278.

Stein CD, Mott LO. Equine infectious anemia in the United State with special reference to the recent outbreak in New England. Proc US Livestock Sanitary Association. 1947; 37:52.

Timoney PJ, McCollum WH, Roberts AW. Detection of the carrier state in stallions persistently infected with equine arteritis virus. Proc Am Assoc Equine Pract. 1986; 32:57-65.

Timoney PJ, McCollum WH, Murphy TW, Roberts AW, Willard JG. The carrier state in equine arteritis virus infection in the stallion with specific emphasis on the venereal mode of virus transmission. J Reprod Fert Suppl. 1987; 35:95-102.

Timoney PJ, McCollum WH. Equine viral arteritis- epidemiology and control. J Equine Vet Sci. 1988; 8:54-59.

Timoney PJ, McCollum WH. Equine viral arteritis. Vet Clin North Am Equine Pract. 1993; 9:295-309.

Turan N, Yilmaz H, Uysal A, Arslan M. Seronegative findings on the investigations of equine infectious Anemia in the Marmara Region of Turkey. Turk J Vet Anim Sci 2002; 26:299-302.

Ün H, Özgünlük İ, Çabalar M. Şanlıurfa ilinde equine viral arteritis enfeksiyonunun serolojik araştırılması. XI. Veteriner Hekimleri Mikrobiyoloji Kongresi, Kemer, Antalya, 21 24 Ekim 2014; 308-309.

Wada R, Kondo T, Fukunaga Y, Kanemaru T. Histopathological and immunofluorescent studies on the uterus of aborted mares experimentally infected with equine arteritis virus. J Equine Sci. 1995; 5:41-43.

Weber H, Beckmann K, Haas L. Case report: equine arteritis virus (EAV) as the cause of abortion in alpacas? DTW 2006; 113:162-163.

Valle H, Carre $\mathbf{H}$. Sur la natur infectieuse de L'anemie du cheval. C R Acad Sci. 1904; 139:331-333.

Yapkıç O, Yavru S, Kale M, bulut O, Şimşek A, Şahna KC. An investigation of equine infectious anemia infection in the Central Anatolia region of Turkey. Tyskr S Afr Vet Ver. 2007; 78:12-14.

Yıldırım Y, Kırmızıgül AH, Tan MT, Gökçe E, Irmak K. Seroprevalence of Equine Viral Arteritis in donkeys in Kars district Turkey. J Anim Vet Adv. 2008; 7:1110-1112.
Y1lmaz H, Özgür NY, Ilgaz A. Serological investigation on the equine viral arteritis. 1st international Veterinary Microbiology Congress, September 25-27, 1996 , İstanbul/Turkey. 